EGU2020-7685

https://doi.org/10.5194/egusphere-egu2020-7685

EGU General Assembly 2020

(c) Author(s) 2020. This work is distributed under

the Creative Commons Attribution 4.0 License.

\title{
Timing and magnitude of vertical-axis rotations in the eastwards- flanking synorogenic sediments of the South-Pyrenean fold-and- thrust belt. Kinematics and origin of the salient curvature.
}

\author{
Charlotte Peigney ${ }^{1,2}$, Elisabet Beamud ${ }^{1,3}$, Óscar Gratacós ${ }^{1,2}$, Luis Valero ${ }^{3,4}$, Ruth Soto ${ }^{5}$, Eduard \\ Roca ${ }^{1,2}$, and Josep Anton Muñoz ${ }^{1,2}$ \\ ${ }^{1}$ Geomodels UB Research Institute, University of Barcelona, Barcelona, Spain (c.peigney@ub.edu) \\ ${ }^{2}$ Dept. de Dinàmica de la Terra i de l'Oceà, University of Barcelona, Barcelona, Spain \\ ${ }^{3}$ Paleomagnetic Laboratory CCiTUB-ICTJA CSIC, University of Barcelona, Barcelona, Spain \\ ${ }^{4}$ Département des sciences de la Terre, Université de Genève, Geneva, Switzerland \\ ${ }^{5}$ Instituto Geológico y Minero de España, Zaragoza, Spain
}

The South-Pyrenean fold-and-thrust belt consists of three major thin-skinned thrust sheets (Bóixols, Montsec and Serres Marginals) made up of uppermost Triassic to Oligocene cover rocks emplaced during Late Cretaceous-Oligocene times. In its central part, it forms a major salient (the Pyrenean South-Central Unit) whose geometry is controlled by the areal distribution of the preorogenic Upper Triassic and synorogenic Eocene salt décollement layers. Both westwards and eastwards, the salient is fringed by Paleogene synorogenic deposits that are deformed by detachment folds with orientations ranging from N-S to E-W. In the western edge of the salient, the varying trend of the folds is a result of synorogenic vertical axis rotations (VAR) which caused the clockwise rotation of the folds from an initial predominant E-W trend to the current NW-SE to NNW-SSE trend. The salient, at least on its western part, developed from a progressive curve originated from divergent thrust transport directions and distributed shortening.

The aim of our study is to get a better understanding of the whole salient, by studying the kinematics of the deformation on the most frontal part of its eastern edge. Here, some sparse anticlockwise rotations have been reported but their origin and their possible relationship with the distribution of the salt décollements has not yet been addressed. For this purpose, 78 paleomagnetic sites have been sampled on the synorogenic upper Eocene-Oligocene materials of the NE Ebro foreland Basin, in the Artesa de Segre area, focusing on the limbs of oblique saltcored anticlines (Ponts, Vilanova de l'Aguda, Cardona) which are detached above the synorogenic Eocene-Oligocene evaporites of the Cardona and the Barbastro formations. VAR analyses principally show anticlockwise rotations similar to those previously identified to the North in the Oliana Anticline, although a small number of clockwise rotations were also detected.

In addition to the VAR analysis, a magnetostratigraphic study of the Eocene-Oligocene continental materials of the northern limb of the Sanaüja Anticline has been conducted in order to constrain the age of these rotations from stratigraphic correlations. The demagnetization of 104 samples 
from a ca. $1100 \mathrm{~m}$ thick magnetostratigraphic section shows Priabonian to Rupelian ages for this succession. The integration of our results on timing, direction and magnitude of foreland VAR with previous paleomagnetic and structural data from both the western and eastern boundaries of the frontal thrust of the Pyrenean South-Central Unit will allow the understanding of the kinematics of the thrust salient as a whole. 